\begin{tabular}{c} 
International Journal of Scientific World, $5(2)(2017) 126-130$ \\
International Journal of Scientific World \\
SPC \\
Website: $\begin{array}{c}\text { www. sciencepubco.com/index. } h \text { h } / I J S W \\
\text { doi: } 10.14419 / i j s w . v 5 i 2.8112 \\
\text { Research paper }\end{array}$ \\
\hline
\end{tabular}

\title{
Responses of Utasi (Gongronema latifolium) to NPK 15:15:15 Fertilizer Rates in a Utisol South-South Nigeria
}

\author{
Agba, O. A, Undie, U. L., Adiaha, M. S *and Osang, P. O. \\ Department of Agronomy (Crop and soil Science), Faculty of Agriculture and Forestry, \\ Cross River University of Technology, Obubra, Cross River State, Nigeria \\ *Corresponding author E-mail: mondaysadiaha@gmail.com
}

\begin{abstract}
Gongronema latifolium (Benth) called Utasi by Igbos and Arokeke by Yorubas belongs to Ascepiadaceae family. It is an herbaceous climbing plant found in the tropical region. The leaves are used for food, culinary, medicinal and other domestic purposes. The plant is found among the wild and is not cultivated in regular farms. It is one of the endanger species that stands the risk of been extinct. Therefore, the study was carried out to determine the responses of Gongronema latifolium to seven rates of NPK 15:15:15 fertilizer during 2014 and 2015 cropping seasons at the Teaching and Research Farm, Agronomy Department, Cross River University of Technology Obubra, Cross River State, Nigeria. The experimental design was a randomized complete block design. Treatments were seven rates; $0 \mathrm{~kg} / \mathrm{ha}, 50,100,150,200,250$ and $300 \mathrm{~kg} / \mathrm{ha}$ of NPK (15:15:15) fertilizer replicated four times. Results showed that application of $300 \mathrm{~kg} / \mathrm{ha}$ of NPK 15:15:15 fertilizer gave a higher number of leaves, branches per plant and tallest plants than the other rates of NPK fertilizer. The highest leaf yields in hectares were obtained in plots treated with $200 \mathrm{~kg} / \mathrm{ha}$ in 2014 and 2015 seasons respectively.

Based on these findings, farmers are advice to domesticate and cultivate Gongronema latifolium with the application of $200 \mathrm{~kg} / \mathrm{ha}$ NPK 15:15:15 fertilizer for optimum growth and leaf yield.
\end{abstract}

Keywords: NPK Fertilizer; Gongronema latifolium; Utasi; Fertilizer Impact; Fertilizer Rate.

\section{Introduction}

Gongronema latifolium (Benth) belongs to the family Asclepiadaceae [1]. It is an herbaceous climbing leaf and a known indigenous plant that grows in the wild tropical rain forest of southern Nigeria.

It is called UtasI by the Igbos and Arokeke by Yoruba's tribes of Nigeria [2]. The leaves of Gongronema latifolium are rich in vitamins, minerals and phytochemicals and is used as vegetables spice for soup and meat preparations [3]. Extracts from the leaves, veins and roots are used for a medicinal purpose for the treatment of diabetes, stomach pains, and worm infestation [4]; [1].

Despite the economic importance of Gongronema latifolium, there is scanty literature information on the agronomic, cultural techniques, fertilizer requires for it domestication and cultivation in regular farms and at the commercial scale in Nigeria.

The crop is currently found in the wild forest where persons especially women and children usually search to harvest as the need arise. Attempt to domesticate the plant is ongoing by some peasants farmers and Researchers who have used either seeds or vine cuttings as propagating materials [5].

Literature shows that the application of mineral fertilizers significantly increased the growth and yield of crops, especially leafy vegetables. [6]; [7]; [8]; [9]. Documented information about the response of Gongronema latifolium to mineral fertilizer, especially NPK based fertilizers are lacking.

Therefore, this study is aimed to determine the rate of NPK 15:15:15 fertilizer that will be appropriate for optimum growth and yield of Gongronema latifolium in Obubra, South-South Nigeria.

\section{Material and methods}

Studies were carried out in the Cross River University of Technology, Department of Agronomy, Teaching and Research Farm, Faculty of Agriculture Obubra, Cross River State, South-South Nigeria during the 2014 and 2015 cropping seasons. The Geographical location of Obubra lies between latitude" $05^{\circ} 59^{\prime}$ and longitude “ $08^{0} 18^{\prime}$ ”'East [10].

\subsection{Land preparation}

Experimental field that measured $24 \times 14$ metres with area of $336 \mathrm{~m}^{2}$ ( $0.336 \mathrm{ha})$ was cleared, ploughed, harrowed and divided into three blocks. Each block was sub-divided into seven plots of $4 \times 3 \mathrm{~m}$ $\left(12 \mathrm{~m}^{2}\right)$ each in April 15 th 2014 and 2015 cropping season respectively. Each plot was separated by $0.5 \mathrm{~m}$ path from adjourning plot. Soil samples were collected at random from 50 different points using steel auger at depth of $0 \mathrm{~cm}-20 \mathrm{~cm}$. The soil samples were bulked together, mixed thoroughly, from where a composite soil sample was collected for laboratory soil analysis, to determine physical and chemical properties of the site using standard laboratory procedures.

\subsection{Planting of Gongronema latifolium}


Gongronema latifolium was propagated vegetatively (by vine cuttings). Mature fresh vine cuttings were obtained from the wild rain forest of Ovonum- Obubra and Ikom local Government Areas Councils, Cross River State, as there is yet no source of improved planting materials. Each vine cuttings measured $30 \mathrm{~cm}-35 \mathrm{~cm}$ long with about 4-5 nodes (buds) were used as planting materials.

Plantings of the vine cuttings were done on $25^{\text {th }}$ April, 2014 and 2015 at a spacing of $70 \times 50 \mathrm{~cm}$ inter and intra row at the depth of 2 $3 \mathrm{~cm}$ with 2-3 nodes covered inside the soil and the other 2-3 nodes outside the soil.

\subsection{Experimental Design}

The experimental design was a Randomized Complete Block Design. Treatments were seven rates of NPK 15:15:15 fertilizer at 0 , $50,100,150,200 ; 250$ and $300 \mathrm{~kg} / \mathrm{ha}$ replicated four times. The fertilizer was applied at four weeks after planting by side binding method.

\subsection{Cultural Practices}

- $\quad$ Staking of seedlings

Gongronema seedlings were stake using bamboo stake at four weeks after planting (WAP).

- Weed control

Weeding was alone manually using hoe on a regular basis to keep the experimental field weed free as possible.

- Harvesting

The leaves of Gongronema latifolium were harvested as green vegetables when needed. The harvesting began at eight weeks after planting and continues at every 3-4-week interval.

During harvesting, only fresh green young succulent leaves were cut using a kitchen knife.

\subsection{Data collection}

Data were collected on the following parameters:

- Number of leaves, branches per plant, plant height (cm)

- Leaf area index: Days to $1^{\text {st }} \& 50 \%$ flowering \& fruiting, dry matter plant fraction.

- Crop growth rate (CGR).

- $\quad$ Fresh leaf yield per plant \& per hectare.

- Dry matter yield per plant \& hectare

- Leaf area index. (LAI);

Leaf Area Index was determined using;

$\mathrm{LAI}=\mathrm{La} \times(\mathrm{p})^{-1}$

Where

LAI=Leaf area index

$\mathrm{La}=$ Total leaf area per plant

$\mathrm{P}=$ feeding area available (for ground support). This supports the view of Radford and Brown [11]

Crop growth rate: (C G R).

Where

$\mathrm{CGR}=$ crop growth rate

$\mathrm{CGR}=\mathrm{W}_{2}-\mathrm{W}_{1 \mathrm{~g} / \mathrm{m} 2 / \text { day }}$

$\mathrm{SA}\left(\mathrm{t}_{2}-\mathrm{t}_{1}\right)$

Were: $\mathrm{CGR}=$ Crop growth rate

$\mathrm{W}_{1}$ and $\mathrm{W}_{2}=$ dry weight at beginning and end of the interval of growth period

$\mathrm{t}_{1}$ and $\mathrm{t}_{2}=$ sampling time 1 and 2

$\mathrm{SA}=$ the area occupied by the plant at sampling

\subsection{Statistical analysis}

Data collected were statistically analyzed using analysis of variance (ANOVA) procedure for randomize complete block design experiments [12]. Separation of treatments means for significant difference was done using Fishers Least Significant Difference (FLSD) at 0.05 probability level as described by Obi [13].

\section{Result and Discussion}

\subsection{Weather condition of the study site}

Summary of the weather data presented on Table 1 shows that the mean annual rainfall, temperature, relative humidity (April - December) were $\left(23214 \mathrm{~mm}, 30.2^{\circ} \mathrm{C}\right.$ and $81.2 \%$ in 2014) and (229.7mm, $30.5^{\circ} \mathrm{C}$ and $79.1 \%$ in 2015 ) cropping seasons respectively and were appropriate for the growth of Gongronema latifolium plant.

Table 1: Summary of Weather Data of Thee Experimental Sites in 2014 and 2015 Cropping Seasons

\begin{tabular}{lllll}
\hline \multirow{2}{*}{ Months } & $\begin{array}{l}\text { Rainfall } \\
(\mathrm{mm})\end{array}$ & \multicolumn{2}{l}{ Temperature $\left({ }^{\circ} \mathrm{C}\right)$} & \multicolumn{2}{l}{ Relative Hu- } \\
& Maximum & Minimum & midity $(\%)$ \\
\hline 2014 Cropping & Season & & & \\
April & 141.3 & 34.2 & 26.2 & 80.3 \\
May & 231.1 & 32.1 & 25.1 & 83.7 \\
June & 351.3 & 30.1 & 24.3 & 85.4 \\
July & 494.2 & 28.3 & 21.5 & 87.3 \\
August & 201.5 & 30.1 & 25.1 & 82.9 \\
September & 311.2 & 27.4 & 27.3 & 84.1 \\
October & 232.7 & 29.7 & 24.2 & 81.7 \\
November & 100.3 & 31.8 & 20.3 & 78.3 \\
December & 27.1 & 28.5 & 19.7 & 67.5 \\
Total & 2091.7 & 272.2 & 213.7 & 731.2 \\
Mean & 232.41 & 30.24 & 23.74 & 81.24 \\
2015 Cropping & Seasons & & & \\
April & 163.2 & 33.5 & 25.8 & 81.1 \\
May & 263.1 & 31.3 & 22.1 & 83.1 \\
June & 537.1 & 30.1 & 23.1 & 87.7 \\
July & 637.5 & 32.3 & 24.3 & 90.8 \\
August & 389.8 & 29.2 & 25.1 & 85.3 \\
September & 421.5 & 28.1 & 31.4 & 87.2 \\
October & 301.2 & 30.4 & 20.3 & 75.5 \\
November & 187.1 & 29.5 & 20.1 & 84.1 \\
December & 15.3 & 29.5 & 20.1 & 65.7 \\
Total & 2915.8 & 273.9 & 212.3 & 740.5 \\
Mean & 323.98 & 30.43 & 23.59 & 82.28 \\
\hline Source & River & & & \\
\end{tabular}

Source: Cross River University of Technology, Obubra Meteorological station.

The soil analysis results in Table 2 indicated that the soil is slightly acidic with $\mathrm{pH}$ of 5.04 in water and $4.90 \mathrm{in} \mathrm{KCl}$ and 5.0 in water and 4.91 in $\mathrm{KCl}$ in 2014 and 2015 seasons respectively. Soil macro organic matter including macro-nutrients (Nitrogen, Phosphorus and Potassium) were low.

Agba [14] and Adiaha [15] work in similar locations had recommended the application of mineral fertilizer to such soils with low nutrients status to increase the growth and yield of crops.

Table 2: Physical and Chemical Properties of the Soil of the Experimental Sites in 2014 and 2015 Cropping Season

\begin{tabular}{lll} 
Soil Properties & $\begin{array}{l}\text { Values } \\
2014\end{array}$ & 2015 \\
\hline Mechanical Properties & & \\
Coarse sand (\%) & 13.4 & 14.1 \\
Fine Sand (\%) & 65.1 & 66.5 \\
Silt (\%) & 18.2 & 19.3 \\
Clay (\%) & 5.2 & 6.4 \\
Textural class & Sandy loam & Sandy loam \\
& & \\
Chemical properties & & \\
pH in water & 5.04 & 5.06 \\
pH in kcl & 4.90 & 4.91 \\
Organic carbon (\%) & 0.82 & 0.83 \\
Organic matter (\%) & 1.26 & 1.32 \\
Nitrogen (\%) & 0.07 & 0,09 \\
Available phosphorus (cmol/kg) & 3.67 & 3.89 \\
Base Saturation (\%) $(\mathrm{cmol} / \mathrm{kg})$ & 1,518 & 1,471 \\
Exchangeable cation & & \\
Potassium & 0.23 & 0.34 \\
Magnesuim & 1.83 & 1.77 \\
Calcuim & 3.41 & 3.29 \\
Sodium & 0.15 & 0.18 \\
Aluminum & 0.11 & 0.12 \\
Hydrogen & 0.62 & 0.68 \\
Cation exchange capacity (Cmol/kg) & 85.3 & 82.1 \\
\hline
\end{tabular}




\subsection{Numbers of Leaves and Branches per Plant}

The application of NPK 15:15:15 fertilizer significantly $(\mathrm{P}=0.05)$ increased the numbers of leaves and branches per plant in all the periods of measurements at 6,12 and 18 weeks after planting (WAP) as shown in table 3. Number of leaves increased with successive increment in the rates of NPK 15:15:15 fertilizer and the age of the plant. The highest number of leaves per plant 112.4 in 2014 and 114.2 in 2015 were recorded in plots that NPK fertilizer were treated with $300 \mathrm{~kg} / \mathrm{ha}$ at 18 weeks after planting (WAP).

On the other hand, fertilizer application has no significant effects on number of branches per plant at the early period of 6 WAP However, the effect of NPK fertilizer on number of branches be- came significant at 12 and $18 \mathrm{WAP}$ and followed similar trend as that recorded on number of leaves per plants.

The analyzed data on plant height showed increased in plant height as Gongronema latifolium age increase from 6-18 WAP. However, taller plants with longer vine length were observed in NPK 15:15:15 fertilizer plots than those plots not treated with fertilizer (control plots).

The significant increase in the vegetative growth parameters (number of leaves, branches, per plant and plant height measured as vine length) in this experiment agrees with the findings of Agba and Enya [16]; Adiaha and Agba [17], who reported significant increase in cucumber and maize (Zea mays L.) growth parameters when NPK fertilizer was applied in cultivating them.

Table 3: Effects of NPK 15:15:15 Fertilizer on the Growth Number of Leaves Branches Per Plant and Plant Height (Cm) of Gongronema latifolium in 2014 and 2015 Cropping Season

\begin{tabular}{|c|c|c|c|c|c|c|c|c|c|c|c|}
\hline \multirow{2}{*}{$\begin{array}{l}\text { NPK 15:15:15 } \\
\text { fertilizer rate } \\
(\mathrm{kg} / \mathrm{ha})\end{array}$} & \multicolumn{3}{|c|}{ No. of leaves per plant } & \multicolumn{3}{|c|}{ No. of Branches per plant } & \multicolumn{4}{|c|}{ Plant Height $(\mathrm{cm})$} & \multirow{2}{*}{$\begin{array}{l}\text { LSD } \\
(0.05)\end{array}$} \\
\hline & $6 \mathrm{WAP}$ & $\begin{array}{l}12 \\
\text { WAP }\end{array}$ & $\begin{array}{l}18 \\
\text { WAP }\end{array}$ & $6 \mathrm{WAP}$ & $\begin{array}{l}12 \\
\text { WAP }\end{array}$ & $\begin{array}{l}18 \\
\text { WAP }\end{array}$ & $6 \mathrm{WAP}$ & $\begin{array}{l}12 \\
\text { WAP }\end{array}$ & $\begin{array}{l}18 \\
\text { WAP }\end{array}$ & Mean & \\
\hline \multicolumn{12}{|c|}{2014 Cropping Season } \\
\hline 0 & $11 . .3$ & 23.1 & 42.4 & 2.4 & 4.1 & 5.3 & 25.3 & 51.4 & 94.2 & 28.82 & 3.1 \\
\hline 50 & 18.2 & 38.2 & 61.3 & 3.2 & 7.3 & 9.2 & 30.5 & 73.5 & 143.1 & 42.71 & 3.4 \\
\hline 100 & 22.3 & 43.3 & 69.2 & 3.3 & 8.1 & 11.3 & 33.6 & 81.3 & 165.3 & 48.62 & 4.2 \\
\hline 150 & 24.2 & 51.1 & 82.3 & 3.1 & 9.2 & 11.4 & 35.7 & 90.6 & 201.2 & 56.53 & 4.5 \\
\hline 200 & 27.2 & 62.3 & 90.2 & 3.3 & 9.3 & 12.3 & 40.1 & 104.3 & 233.7 & 59.34 & 5.1 \\
\hline 250 & 29.1 & 81.4 & 103.2 & 3.1 & 10.2 & 14.1 & 44.3 & 121.7 & 256.8 & 73.78 & 6.2 \\
\hline 300 & 30.3 & 94.2 & 112.4 & 4.0 & 10.1 & 14.3 & 49.7 & 152.3 & 304.5 & 85.76 & 7.2 \\
\hline Mean & 23.2 & 56.2 & 93.5 & & 8.32 & 11.1 & 39.03 & 96.4 & 199.8 & & \\
\hline $\operatorname{LSD}(0.05)$ & 1.3 & 3.0 & 5.1 & N.S & 1.01 & 1.01 & 2.1 & 3.3 & & & \\
\hline \multicolumn{12}{|c|}{2015 Cropping Season } \\
\hline 0 & 10.2 & 21.3 & 39.3 & 1.4 & 3.4 & 4.4 & 21.8 & 49.6 & 101.5 & 28.11 & 2.2 \\
\hline 50 & 19.1 & 36.3 & 55.2 & 3.1 & 6.3 & 8.2 & 32.3 & 68.9 & 137.3 & 40.74 & 3.4 \\
\hline 100 & 21.3 & 41.2 & 74.1 & 3.2 & 7.4 & 10.3 & 37.1 & 80.2 & 157.2 & 46.86 & 4.2 \\
\hline 150 & 23.2 & 53.1 & 81.4 & 3.3 & 8.4 & 10.2 & 41.3 & 89.8 & 212.5 & 58.13 & 4.6 \\
\hline 200 & 26.1 & 60.4 & 93.1 & 3.2 & 9.3 & 11.1 & 48.8 & 112.5 & 241.4 & 67.32 & 5.2 \\
\hline 250 & 28.2 & 83.1 & 101.3 & 4.11 & 11.1 & 12.3 & 53.1 & 131.4 & 253.6 & 75.3 & 6.7 \\
\hline 300 & 31.4 & 96.3 & 114.2 & 4.0 & 8.2 & 14.2 & 57.2 & 158.4 & 311.71 & 83.51 & 7.3 \\
\hline Mean & 22.9 & 55.96 & 79.8 & 3.28 & 0.11 & 10.1 & 41.6 & 98.4 & 202.1 & & \\
\hline $\operatorname{LSD}(0.05)$ & 1.5 & 3.5 & 4.6 & NS & 1.01 & 1.2 & 2.3 & 3.2 & & & \\
\hline
\end{tabular}

Table 4: Effects of NPK 15:15:15 Fertilizer on the Dry Matter (G/Plant) Leaf and Vine Weight of Grongronema latifoliumin in 2014 and 2015 Cropping Season

\begin{tabular}{|c|c|c|c|c|c|c|c|c|}
\hline \multirow{2}{*}{$\begin{array}{l}\text { NPK 15:15:15 fertilizer } \\
\text { rate }(\mathrm{kg} / \mathrm{ha})\end{array}$} & \multicolumn{3}{|c|}{ Leaf dry weight per plant } & \multicolumn{4}{|c|}{ Vine dry weight per plant(g) } & \multirow{2}{*}{$\begin{array}{l}\text { LSD } \\
(0.05)\end{array}$} \\
\hline & $6 \mathrm{WAP}$ & $\begin{array}{l}12 \\
\text { WAP }\end{array}$ & $\begin{array}{l}18 \\
\text { WAP }\end{array}$ & $6 \mathrm{WAP}$ & $\begin{array}{l}12 \\
\text { WAP }\end{array}$ & $\begin{array}{l}18 \\
\text { WAP }\end{array}$ & Mean & \\
\hline \multicolumn{9}{|l|}{2014 Cropping Season } \\
\hline 50 & 42.27 & 73.52 & 147.52 & 26.11 & 47.31 & 154.35 & 81.81 & \\
\hline 100 & 50.35 & 87.33 & 175.15 & 33.27 & 65.27 & 181.42 & 98.80 & \\
\hline 150 & 61.42 & 94.15 & 192.26 & 45.15 & 139.16 & 196.16 & 121.40 & \\
\hline 200 & 74.56 & 113.26 & 215.44 & 50.30 & 190.35 & 221.37 & 144.21 & \\
\hline 250 & 82.18 & 141.11 & 253.12 & 69.22 & 112.17 & 270.42 & 154.70 & \\
\hline 300 & 66.24 & 97.53 & 183.33 & 48.33 & 96.72 & 191.10 & 113.88 & \\
\hline Mean & 58.62 & 94.86 & 178.3 & 41.94 & 87.34 & 157.62 & & \\
\hline $\operatorname{LSD}(0.05)$ & 5.12 & 6.31 & 10.12 & 3.02 & 7.51 & 17.21 & & \\
\hline \multicolumn{9}{|l|}{2015 Cropping Season } \\
\hline 0 & 37.15 & 60.23 & 90.11 & 23.15 & 41.32 & 54.74 & 51.12 & \\
\hline 50 & 40.32 & 82.14 & 127.50 & 35.34 & 58.14 & 75.33 & 69.80 & \\
\hline 100 & 52.97 & 89.85 & 181.41 & 39.79 & 70.22 & 91.45 & 87.12 & \\
\hline 150 & 64.28 & 95.43 & 209.55 & 42.34 & 77.15 & 105.31 & 99.18 & \\
\hline 250 & 89.13 & 150.03 & 251.31 & 63.24 & 107.58 & 231.16 & 148.82 & \\
\hline 300 & 70.07 & 95.33 & 177.38 & 50.32 & 79.95 & 107.31 & 96.73 & \\
\hline Mean & 61.07 & 97.55 & 166.35 & 43.76 & 73.93 & 113.51 & & \\
\hline $\operatorname{LSD}(0.05)$ & 4.92 & 6.53 & 11.25 & 3.51 & 7.73 & & & \\
\hline
\end{tabular}

Table 4 Shows the effects of NPK 15:15:15 fertilizer on dry matter of Gongronema latifolium.

Results of analysis of variance (ANOVA) indicates significant high leaf and vine dry matter weight per plant in NPK fertilizer treated plots than the non-fertilized plots.

At 6,12 and 18 WAP, leaf and vine dry matter weight per plant increase with increase in NPK 15:15:15 fertilizer rates. However, the increase in dry matter weight was up to $250 \mathrm{~kg} / \mathrm{ha}$ rate of NPK fertilizer beyond which both leaf and vine dry matter weight per plant began to decrease as the rate of NPK fertilizer increase.

The application of 300kg/ha of NPK 15:15:15 fertilizer produced lower leaf and vine dry matter weight as compared to the lower rate of $200 \mathrm{~kg} / \mathrm{ha}$. The highest $(\mathrm{P}=0.05)$ leaf dry weight $(253.12$ per plant in 2004 and $251.31 \mathrm{~g} / \mathrm{plant}$ in 2015) and vine $(112.17 \mathrm{~g} / \mathrm{plant}$ in 2014 and $231.16 \mathrm{~g} / \mathrm{plant})$ received $250 \mathrm{~kg} / \mathrm{ha}$ of NPK 15:15:15 fertilizer. 
These significantly high leaf and vine dry weights per plant recorded in NPK 15:15:15 fertilizer treated plots especially with $250 \mathrm{~kg} / \mathrm{ha}$ showed higher dry weight per plant than the other fertilizer rates, this corroborates with the work of Agba and Enya [16]; Ainika, and Amens[18] that reported similar effects of fertilizer on the growth of Amarathus vegetable leaf and growth rates.

\subsection{Leaf and Vine}

The analyzed result on Gongronema latifolium leaf and vine growth rate measured as dry mater accumulation in plants parts at regular period of 5.28 days interval is summarized in table 5 .
The result revealed that leaf and vine growth rate was low at the early period of $30-58$ and $58-86$ days after planting (DAP).

However, between (86 - 114) DAP and (114 - 142 DAP), leaf and vine growth rate double with plots treated with NPK 15:15:15 fertilizer recording higher leaf and vine growth rate than the plots not treated with NPK fertilizer.

Maximum leaf and vine growth rates of leaf $\left(5.0383 \mathrm{~g} / \mathrm{m}^{2} /\right.$ day in $2015)$ and vine $\left(4.4367 \mathrm{~g} / \mathrm{m}^{2} /\right.$ day in 2014 and $4.537 \mathrm{~g} / \mathrm{m}^{2} /$ day in 2015 were observed between the period of $86-114$ DAP in the two cropping seasons (2014 and 2015) respectively. Agba et al.[6] obtained similar leaf and vine growth rates in Mucuna flagellipes plants treated with Urea fertilizer.

Table 5: Effect of NPK 15"15:15 Fertilizer on Fresh Leaf Yield of Utasi Gongronema latifolium in 2014 and 2015 Cropping Season

\begin{tabular}{|c|c|c|c|c|c|c|c|c|c|c|c|c|c|c|}
\hline \multirow{2}{*}{$\begin{array}{l}\text { NPK 15"15:15 } \\
\text { fertilizer rate } \\
(\mathrm{kg} / \mathrm{ha})\end{array}$} & \multicolumn{6}{|c|}{ Leaf yield per plant (g) } & \multicolumn{6}{|c|}{ Leaf yield per hectare ( $\mathrm{t} / \mathrm{ha}$ ) } & \multirow[t]{2}{*}{ Means } & \multirow{2}{*}{$\begin{array}{l}\text { LSD } \\
(0.05)\end{array}$} \\
\hline & 6 & 8 & 12 & 16 & 20 & 24 & 6 & 8 & 12 & 16 & 20 & 24 & & \\
\hline \multicolumn{15}{|c|}{2014 Cropping Season } \\
\hline 0 & 54.3 & 71.1 & 83.4 & 94.3 & 111.5 & 72.3 & 0.12 & 0.31 & 0.42 & 0.51 & 0.59 & 0.63 & 40.7 & 0.10 \\
\hline 50 & 83.2 & 98.6 & 114.7 & 124.8 & 153.1 & 94.6 & 0.45 & 0.72 & 1.03 & 1.44 & 1.75 & 0.54 & 56.2 & 0.11 \\
\hline 100 & 107.4 & 130.7 & 153.5 & 175.2 & 201.3 & 112.3 & 0.61 & 0.91 & 1.34 & 1.68 & 1.83 & 0.73 & 80.9 & 2.3 \\
\hline 150 & 121.5 & 162.1 & 181.6 & 197.3 & 245.8 & 124.1 & 0.82 & 1.03 & 1.57 & 1.93 & 2.14 & 1.08 & 87.3 & 3.5 \\
\hline 200 & 153.7 & 179.2 & 193.4 & 232.5 & 261.4 & 132.3 & 0.94 & 1.21 & 1.86 & 2.05 & 2.31 & 1.24 & 86.84 & 4.1 \\
\hline 250 & 162.9 & 191.5 & 211.7 & 251.4 & 285.2 & 151.6 & 0.99 & 1.43 & 1.93 & 2.41 & 2.14 & 1.53 & 105.41 & 5.2 \\
\hline 300 & 110.2 & 142.3 & 162.3 & 183.2 & 194.8 & 101.5 & 0.53 & 0.51 & 0.82 & 1.02 & 1.41 & 0.86 & 74.44 & \\
\hline Mean & 113.3 & 139.3 & 157.2 & 179.8 & 207.6 & 112.7 & 0.64 & 0.87 & 1.28 & 1.58 & 1.84 & 0.89 & & \\
\hline $\operatorname{LSD}(0.05)$ & 20.2 & 15.4 & 16.1 & 17.5 & 19.4 & 18.5 & 0.01 & 0.01 & 0.01 & 0.01 & 0.01 & 0.01 & & \\
\hline \multicolumn{15}{|c|}{2015 Cropping Season } \\
\hline 0 & 52.6 & 73.2 & 80.2 & 91.7 & 116.3 & 67.4 & 0.14 & 0.30 & 0.41 & 0.53 & 0.62 & 0.12 & 41.30 & 0.12 \\
\hline 50 & 80.5 & 96.3 & 109.5 & 126.1 & 149.4 & 95.3 & 0.47 & 0.69 & 1.04 & 1.06 & 1.72 & 0.52 & 55.30 & 0.13 \\
\hline 150 & 124.2 & 160.8 & 179.8 & 190.7 & 239.8 & 122.7 & 0.81 & 1.04 & 1.55 & 1.94 & 2.16 & 1.08 & 56.58 & 3.4 \\
\hline 200 & 147.3 & 181.3 & 190.5 & 231.6 & 260.7 & 133.0 & 0.95 & 1.23 & 1.88 & 2.07 & 2.37 & 1.26 & 98.18 & 4.3 \\
\hline 250 & 165.4 & 190.8 & 209.6 & 148.3 & 283.1 & 153.3 & 0.98 & 1.45 & 1.95 & 2.43 & 2.68 & 1.58 & 105.13 & 5.1 \\
\hline 300 & 106.3 & 140.3 & 157.2 & 181.3 & 192.3 & 102.4 & 0.52 & 0.51 & 0.82 & 1.04 & 1.46 & 0.87 & 73.79 & \\
\hline Mean & 112.66 & 141.10 & 153.9 & 177.4 & 205.8 & 111.2 & 0.64 & 0.87 & 1.28 & 1.52 & 1.85 & 0.80 & & \\
\hline $\operatorname{LSD}(0.05)$ & 21.1 & 16.1 & 15.4 & 17.8 & 19.3 & 18.7 & 0.01 & 0.01 & 0.01 & 0.01 & 0.01 & 0.01 & & \\
\hline
\end{tabular}

Table 5 also shows the result of the summary of the analysis of variance of Leaf Area Index (LAI of Gongronema latifolium as influenced by NPK 15:15:15 fertilizer at 6,12 and 18 WAP. Leaf area index increased gradually at $6-12$ WAP with NPK fertilizer recorded higher leaf area index value than the non-fertilizer plants. At 12 WAP, the application of $150-200 \mathrm{~kg} / \mathrm{ha}$ did not show any significant different on the LAI.

However at 18 WAP, LAE increase with incremental rate of NPK fertilizer, the highest value of LAI (4.134 in 2014 and 4.151 in 2015 ) was obtained at $300 \mathrm{~kg} / \mathrm{ha}$ of NPK fertilizer rate. This finding agrees with the research outcome of Asiegbu and Agba [19] reporting high LAI values as result of NPK fertilizer application on Mmucuna flagellipes.

The result also shows that the application of NKP fertilizer significantly promoted earlier flowering and fruiting of Congronema latifoluim as compared to plants that were not applies with fertilizer. Throughout the periods of duration of the studies (2014 2015) all cases where $250 \mathrm{~kg} / \mathrm{ha}$ of fertilizer were applied significantly $(P=0.05)$ flower and fruit earlier than plots that received either lower or higher rates of NPK fertilizer. Similarly, Agba [20] observed earlier flowering in Mucuna flagellipes in response to NPK fertilizer application.

Table 5 further showed the analysis of variance result of the effects of NKP fertilizer on fresh leaf yield of Gongronema latifoli$u m$. The application of NKP fertilizer significantly $(\mathrm{P}=0.05)$ increased the fresh leaf yield of the plant/fresh leaf yield per plant and per hectare were higher in plots treated with $250 \mathrm{~kg} / \mathrm{ha}$ as compare to other plots that were treated with lower or higher rates of NPK fertilizer in both 2014 and 2015 cropping seasons. This result is in line with the findings of Aninika and Amans [18] that obtained increased fresh leaf yield due to NPK fertilizer application in Amaranthus species.

\section{Conclusion}

The result of the study showed that the application of different rates of NPK 15:15:15 fertilizer significantly increased the growth and yield of Gongronema latifolium. The used of $300 \mathrm{~kg} / \mathrm{ha}$ gave highest vegetative growth such as number of leaves, branches, and LAI. While $250 \mathrm{~kg} / \mathrm{ha}$ promoted earlier flowering, fruiting, dry mater weight of leaf, vine crop growth rate and fresh leaf yield per plant and hectare. Farmers are advice to apply $250 \mathrm{~kg} / \mathrm{ha}$ NPK 15: 15:15 fertilizer for optimum growth and yield of Congrone malatifolium.

\section{References}

[1] Burkill, H. M. (1985). The useful plants of West Africa. Royal Botenical Gardens.Second edition Vol. 1.960 p.

[2] Emeka, E. J. and Obiora, O. (2009). Effect of long term composition of diet supplemented with Gongronema latifolium Benth on some biochemical and histological paramenters in male albino rats. Journal of Biological Sciences 9 (8) 859-865. https://doi.org/10.3923/jbs.2009.859.865.

[3] Morebise, O. Fafunso, M.A., Mokinde, J.M. Oleyide, O.A. and Awe, E. O. (2002). Anti-inflammatory property of the leaves of Gongronema latifolium Phytotheraph Research 16 (1) ! 75-77.

[4] Akah, P.A. and Okafor, G.I. (1992). Blood sugar lowering effects of Gongronema latifolium in an experimental Emel. Phytotheraph Research 6: 171 - 175. https://doi.org/10.1002/ptr.2650060318.

[5] Agbo, C. U., Obi, I.U. and Omaliko, O. P. E. (2006). Initiation and growth of shoot of Gongronema latifolium. Benth Stem cuttings in difference rooting Media. African Journal of Biotechnology. (6) $425-425$.

[6] Agba, O.A., Adiaha, M.S, Asiegbu, J. E. and Mbah, B.N. (2016). Effect of plant population on the growth and yield of Mucuna fla- 
gellipes (Vogal ex Hook) in all ultisa, South Nigerian.World Scientific New, 60 (2016) 1-12.

[7] Ogar, A. (2009). Wpl/ywnanocza steczeksrebranarozwójgrzybów. Master's thesis.Jagiellonian University, Krakow, Poland.97 pp. [In Polish].

[8] Ali, G.A. (2005). Use of manure and fertilizer as soil management techniques for sustainable crop production. Paper presented at workshop by Taraba State local government Service Commission on 6 and 9 December, Nigeria Journal of Agriculture Vu. 7 NO. 3 Pp 126.

[9] Ainika, J. N. and Amans, E. B. (2011). Growth and yield responses of vegetable Amaranthus to NPK fertilizer and farm yard manure. Proceedings of $29^{\text {th }}$ Annual National Conference of Horticultural Society of Nigeria Vol. 5 Pp 375.

[10] Cross River Agricultural Development project (CRADP) (1992). Report on wet lands up of Cross River State. Pp 115.

[11] Radford, P.J. and Brown, A. C. (1984). Growth analysis formula Their use and abuse. Crop Sci. 7 (3) 171 - 175. https://doi.org/10.2135/cropsci1967.0011183X000700030001x.

[12] Gomez, K. A. and Gomez, A. A. (1984). Statistical Procedures for Agricultural Research. Second edition. John Wiley and Sons Inc. New York, USA.

[13] Obi, I. U. (2002). Statistical methods for detecting differences between treatments means for field and laboratory experiments. Second Edition published in Nigerian by A. P. Express published Limited 3 Obollo Road, Nsukka, Nigeria 117pp.

[14] Agba, O.A (2005). Responses of cucumber (cucumis Sativa L.) to Fertilizer. Journal of Agricultural Science. Vol. 4, 2: 165-168.

[15] Adiaha, M. S. (2016). Influence of Mineral Fertilizer on the Growth of Maize (Zea mays L.) and Soil Fertility Improvement for Food Security, Environmental Development and Sustainable Agriculture. World Scientific News, 56: 189-216

[16] Agba, O.A. and Enya, V, E, (2005). Responses of cucumber (cucumis Sativa L.) to nitrogen in Obubra Cross River State. Global Journal of Agricultural Science.Vol. 4 NO. 2: 165-167.

[17] Adiaha, M. S. and Agba, O. A. (2016). Influence of different methods of fertilizer application on the growth of maize (Zea mays $L$.) for increase production in South Nigerian World Scientific News 54: 73-86.

[18] Ainika, J. N. and Amens, E. B. (2011). Growth and yield response of vegetable Amaranthus to NPK 15: 15: 15 fertilizer and farm yard manure at samara, Nigeria. Proceedings of $29^{\text {th }}$ Annual National Conference of Horticultural Society of Nigeria Volume 5 Pp. 325.

[19] Asiegbu J.E and Agba, O.A. (2008). Studies on yield and yield component response ofMucuna flagellipes to lime and phosphorusapplications under field culture in a tropical ultisol. Journal of Tropical Agriculture, Food, Environment and Extension, 7 (1).5865.

[20] Agba O. A. (2014). Effects plant population, mycorrihza inoculant, oka intercropped on the growth and yield Mucuna flagellipes (Vogel ex Hook) PhD Thesis, University of Nigeria, Nsukka, Enugu state, Nigeria. Pp. 61. 